\title{
PENERAPAN WORK-BASED LEARNING TERHADAP PRAKTIK PEMASANGAN KERAMIK MAHASISWA PENDIDIKAN TEKNIK BANGUNAN
}

\author{
Nono Sebayang1, Syafiatun Siregar ${ }^{2}$, Enny K. Sinaga ${ }^{3}$ \\ 1,2,3 Dosen Pengajar Jurusan Pendidikan Teknik Bangunan, Fakultas Teknik, UNIMED, Medan \\ Surel : sby_nono@yahoo.co.id \\ Diterima : 26 November 2017; Disetujui : 30 November 2017
}

\begin{abstract}
ABSTRAK
Praktik kerja batu dan beton adalah salah satu matakuliah yang ada pada semester ketiga di Program Studi Pendidikan Teknik Bangunan Fakultas Teknik Unimed. Hasil evaluasi semester, secara praktik kemampuan mahasiswa masih rendah pada mata kuliah praktik kerja batu beton. Sementara kompetensi/ pengetahuan praktik kerja batu dan beton sangat membantu mahasiswa ketika mereka terjun di pada umumnya Praktik Kerja Lapangan Industri (PKLI) yang dilakukan pada semester 5 dan pada khususnya ketika mereka memasuki dunia kerja. Untuk mencapai hasil yang maksimal, maka perlu dilakukan pembelajaran yang lebih komprehensif yaitu dengan pembelajaran berbasis kerja (Work-based Learning/WBL). Tujuan dari penelitian ini adalah untuk mengukur kompetensi mahasiswa dalam pemasangan keramik dengan work-based learning. Metode penelitian dilakukan dengan pengamatan langgsung yang dilakukan oleh peneliti dan oleh dosen pengampu mata kuliah terhadap tingkat keaktifan mahasiswa. Hasil penelitian berdampak terhadap peningkatan kompetensi mahasiswa dalam pemasangan keramik dengan work-based learning. Peningkatan juga terlihat dari hasil belajar mahasiswa yang dilakukan dengan pre-test dan post-test
\end{abstract}

Kata Kunci : concrete work, work-based learning, learning outcomes

\begin{abstract}
The practice of stone and concrete work is one of the existing courses in the third-semester Program Building Engineering, Faculty of Engineering in Unimed. The result of semester evaluation, the practical ability of student still low in concrete stone work practice class. While the competence/knowledge of stone and concrete work practices is very helpful for students when they plunge in general Praktik Kerja Lapangan Industri (PKLI) conducted in semester 5 and in particular when they enter the world of work. To achieve maximum results, it is necessary to do a more comprehensive learning with work-based learning (WBL). The purpose of this research is to measure students' competence in the installation of ceramics with work-based learning. The research method is done by direct observation conducted by the researcher and by the lecturer of the lecturer on the student activity level. The results of the research have an impact on the improvement of students' competence in the installation of ceramics with work-based learning. The improvement was also seen from the result of student learning done with pre-test and post-test.
\end{abstract}

Keywords: concrete work, Work-based Learning, learning outcomes

\section{Pendahuluan}

Praktik kerja batu dan beton adalah salah satu matakuliah yang ada pada semester 3 di Program Studi Pendidikan Teknik Bangunan (Prodi PTB) Fakultas Teknik Unimed. Mata kuliah ini adalah mata kuliah praktek yang diasuh oleh beberapa tim dosen Prodi dan dilakukan di workshop jurusan PTB. Metode pembelajaran yang dilakukan oleh dosen adalah dengan metode pembelajaran praktek langsung di workshop. Praktik kerja yang dilakukan hanya pemasangan bata, teknik molding dan pemasangan keramik sederhana. Oleh karena itu perlu kiranya pelaksana pendidik atau dosen sebagai tenaga pengajar /pendidik yang secara langsung terlibat dalam proses belajar mengajar, memegang peranan 


\section{Nono Sebayang - Syafiatun Siregar - Enny K. Sinaga}

peningkatan kualitas pembelajaran dan prestasi belajar yang akan dicapai oleh peserta didiknya. Dengan adanya strategi yang tepat, berkualitas dan cocok, maka diharapkan tujuan pembelajaran dapat tercapai. (Sanjaya, 2005 : 99)

Berdasarkan pengamatan dan evaluasi dari pencapaian hasil belajar praktik kerja batu dan beton masih rendah. Mahasiswa mendapat pembelajaran langsung dilapangan dengan pengawasan dosen pengampu. Hasil evaluasi semester, secara praktik kemampuan mahasiswa masih rendah untuk mencapai kompetensi yang diharapkan. Sementara kompetensi/ pengetahuan praktik kerja batu dan beton sangat membantu mahasiswa ketika mereka terjun di pada umumnya Praktik Kerja Lapangan Industri (PKLI) yang dilakukan pada semester 5 dan pada khususnya ketika mereka memasuki dunia kerja. Umumnya mahasiswa kurang pemahaman dalam praktik pemasangan keramik yang baik dan benar, hal ini dapat dilihat dengan rendahnya kemampuan penalaran mahasiswa dalam praktik di laboratorium. Untuk mencapai hasil yang maksimal, maka perlu dilakukan pembelajaran yang lebih komprehensif yaitu dengan pembelajaran berbasis kerja (Workbased Learning/WBL). Pembelajaran berbasis kerja (WBL) adalah pembelajaran yang dilakukan dengan membuat lapangan praktik sesuai dengan lapangan kerja dan dibantu oleh dosen pengampu mata kuliah praktik. Diharapkan mahasiswa dapat mengaplikasikan ilmunya sesuai dengan keadaan lapangan dan mendapat kompetensi pemasangan keramik yang baik dan benar dibawah pembelajaran berbasis kerja.

Tujuan yang ingin dicapai dalam penelitian ini adalah untuk untuk melakukan pembelajaran berbasis kerja, meningkatkan kemampuan / kompetensi pemasangan keramik. Serta meningkatkan hasil belajar mahasiswa praktik kerja batu dan beton.

\section{Kajian Pustaka}

\subsection{Work Based Learning}

Pembelajaran berbasis kerja (WBL) bukanlah suatu tipe kegiatan pembelajaran baru. Dalam hal ini, sejarah mencatat hal yang terkait, misalnya, dengan berbagai jenis magang. Tetapi tidak demikian halnya di pendidikan tinggi, bidang-bidang seperti kedokteran, pendidikan, dan pekerjaan sosial telah memasukkan pembelajaran berbasis kerja sebagai elemen sentral dalam program selama bertahun-tahun. Pendidikan tinggi selalu dikaitkan dengan persiapan untuk bekerja, terutama dalam kaitannya dengan masuk ke profesi.

Penelitian yang dilakukan oleh Eraut (Linehan, 2008: 14) pada penelitian pendidikan, khususnya di tingkat tersier, menjelaskan adanya kesenjangan antara pengetahuan yang dibutuhkan di tempat kerja dan pengetahuan dan keterampilan yang dihasilkan melalui pendidikan formal. Eraut mengklasifikasikan pengetahuan program pendidikan kejuruan dan profesional diberikan sebagai berikut: a) pengetahuan teoritis, b) pengetahuan metodologis, c) keterampilan praktis dan teknik, d) keterampilan umum, dan e) pengetahuan umum tentang pekerjaan yang bersangkutan.

Boud dan Garrick (1999, dalam Ball I, 2010: 4) menyatakan WBL adalah pelajaran di tempat kerja yang tidak hanya berkaitan dengan kompetensi langsung di tempat kerja, tetapi merupakan investasi dalam menilai kemampuan umum pekerja secara teknis dan spesifik, serta pemanfaatan pengetahuan dan kemampuan di mana pun mereka bekerja. Pembelajaran berbasis kerja terletak dalam konteks pergeseran paradigma dari 'masyarakat industri' ke 'masyarakat pengetahuan' (Rohlinetal, 1998 dalam Linehan, 2008: 20).

Hasil-hasil penelitian mutakhir menyimpulkan bahwa pemanfaatan Pendekatan Pembelajaran Berbasis Tempat Kerja (PBTK) atau Work-Based Learning (WBL) dalam pendidikan memiliki pengaruh positif dalam prestasi (achievement), motivasi (motivation), dan kelanjutan pendidikan (continuing education) (Bailey \& Merrit, 1997). Riset dan studi evaluasi pada WBL menunjukkan adanya korelasi antara luaran (outputs) dan dampak (outcomes) lulusan dengan struktur pembelajaran yang sekolah dan industri berikan dalam pengalaman di tempat kerja. (Lynch \& Harnish, 1998; Fallow \& Weller, 2000; Braham \& Pickering, 2007; Garnett, 2008).

Dari berbagai defenisi WBL yang dikemukan dapat diambil kesimpulan bahwa Pembelajaran Berbasis Kerja adalah pembelajaran yang dilakukan secara formal maupun informal yang dilakukan ditempat kerja yang berwujud pengalaman kerja atau bimbingan kerja untuk dapat mengembangkan sikap, pengetahuan, keterampilan, pencerahan, perilaku dan kebiasaan, yang pada akhirnya untuk meningkatkan kompetensi peserta didik sesuai dengan lapangan kerja yang akan ditempuhnya 


\section{Penerapan Work-Based Learning Terhadap Praktik Pemasangan Keramik Mahasiswa Pendidikan Teknik Bangunan}

\subsection{Sintaks Work Based Learning}

Sintaks dari Work-Based Learning Praktik batu beton yang dijelaskan pada Tabel 1 sebagai berikut:

Tabel 1 Sintaks Work-Based Learning

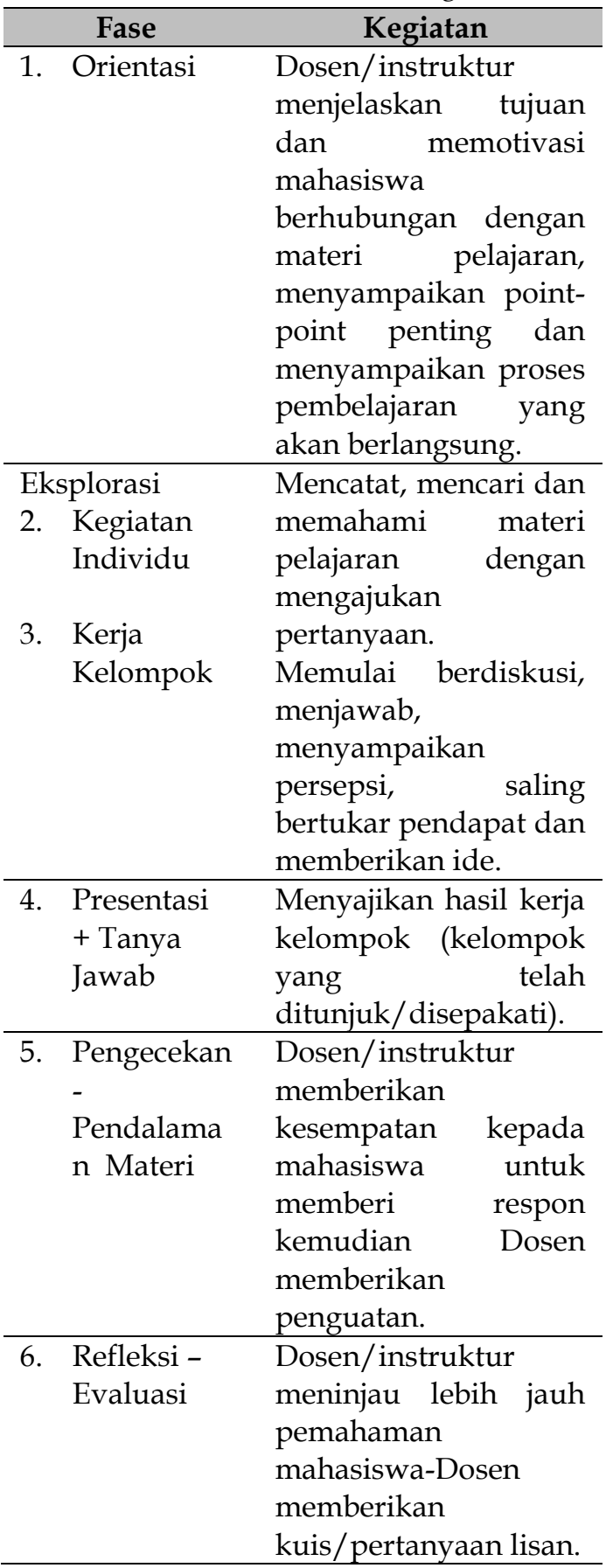

\section{Metodologi}

Penelitian bertujuan untuk meningkatkan kompetensi dan kemampuan praktik kerja batu dan beton mahasiswa melalui pembelajaran Berbasis kerja. Proses upaya peningkatan mutu/kompetensi pembelajaran yang dilakukan dibawah pengawasan dosen pengampu dengan membuat pembelajaran seperti di lapangan kerja. Pelaksanaan dilakukan bertahap dari untuk pembelajaran berbasis kerja yaitu pengenalan alat pelindung diri (APD), pengenalan alat dan bahan, kemampuan pemasangan keramik secara vertikan dan horizontal dengan menggunakan WBL dan evaluasi hasil belajar dengan menerapkan WBL.

\section{Hasil dan Pembahasan}

Penelitian pembelajaran berbasis kerja yang dilakukan di workshop Pendidikan Teknik Bangunan (PTB) Fakultas Teknik Unimed. Awal penelitian dilakukan dengan mendata mahasiswa yang mengambil mata kuliah praktik batu beton. Mahasiswa yang mengambil mata kuliah praktik batu beton adalah mahasiswa PTB semester tiga yang berjumlah 30 orang. Selanjutnya mahasiswa ini dibagi menjadi 4 kelompok dengan masingmasing kelompok terdiri dari $6-7$ orang perkelompok.

Tahap awal dilakukan adalah dengan mengatakan pretest dan pengamatan/observasi untuk meng-etahui kemampuan awal dari peserta WBL yang dilakukan pada minggu/ pertemuan pertama. Kemampuan awal yang diamati/observasi adalah kemam puan pengenalan dan penggunaan Alat

Pelindung Diri (APD), kemampuan mengenal alat, kemam-puan mengenal bahan, kemampuan mengkomposisikan bahan. Masing-masing peserta diamati secara mandiri oleh peneliti.

Selanjutnya penelitian dilakukan selama 4 kali pertemuan /minggu dengan durasi $4 \times 50$ menit. Peng-amatan dilakukan oleh peneliti dengan melakukan pengisian instrumen yang telah disediakan. Untuk pretest dila-kukan dengan melakukan test terhadapa peserta melalui soal isian yang telah disediakan. Selain peng-amatan juga dilakukan wawancara terhadap peserta maupun dosen pengampu mata kuliah.

Tabel 2 bawah ini adalah aspek yang diukur dari peserta (mahasiswa) dalam mengikuti WBL. Aspek yang diukur dari peserta WBL yang terdiri dari 14 aspek. Keempatbelas aspek tersebut dinilai diawal pembelajaran sebelum menggunakan WBL (Minggu/pertemuan I) dan selanjutnya dinilai setelah mendapatkan WBL melalui 4 minggu/pertemuan. Aspek ini dilakukan dengan cara pengamatan oleh peneliti maupun wawancara tersstruktur 


\section{Nono Sebayang - Syafiatun Siregar - Enny K. Sinaga}

dengan dosen pengampu mata kuliah. Penilaian aspek dilakukan dengan menggunakan skala likert untuk mendapatkan hasil kuantitatif

Tabel 2. Aspek Yang Diukur Dari Peserta WBL (1)

\begin{tabular}{|c|c|c|c|c|}
\hline \multirow{2}{*}{ No } & \multirow{2}{*}{$\begin{array}{c}\text { Aspek yang } \\
\text { diukur dari } \\
\text { peserta }\end{array}$} & \multicolumn{3}{|c|}{$\begin{array}{c}\text { Minggu/pertemuan } \\
(\%)\end{array}$} \\
\hline & & I & II & III \\
\hline 1 & $\begin{array}{l}\text { Kemampuan } \\
\text { mengenal Alat } \\
\text { Pelindung Diri }\end{array}$ & 56,67 & 66,67 & 73,33 \\
\hline 2 & $\begin{array}{l}\text { Kemampuan } \\
\text { mengenal alat }\end{array}$ & 46,67 & 50,00 & 56,67 \\
\hline 3 & $\begin{array}{l}\text { Kemampuan } \\
\text { mengenal Bahan }\end{array}$ & 50,00 & 56,67 & 66,67 \\
\hline 4 & $\begin{array}{l}\text { Kemampuan } \\
\text { menggunakan } \\
\text { alat }\end{array}$ & 33,33 & 46,67 & 53,33 \\
\hline 5 & $\begin{array}{l}\text { Kemampuan } \\
\text { mengkomposisis } \\
\text { kan bahan }\end{array}$ & 50,00 & 66,67 & 83,33 \\
\hline 6 & $\begin{array}{l}\text { Memperhatikan } \\
\text { penjelasan dosen }\end{array}$ & 40,00 & 50,00 & 73,33 \\
\hline 7 & $\begin{array}{l}\text { Keberanian } \\
\text { bertanya }\end{array}$ & 43,33 & 53,33 & 60,00 \\
\hline 8 & $\begin{array}{l}\text { Kemampuan } \\
\text { bekerja mandiri }\end{array}$ & 33,33 & 60,00 & 70,00 \\
\hline 9 & $\begin{array}{l}\text { Berkomunikasi } \\
\text { dan } \\
\text { berpartisipasi } \\
\text { dengan baik }\end{array}$ & 33,33 & 43,33 & 60,00 \\
\hline 10 & $\begin{array}{l}\text { Kemampuan } \\
\text { kerja tim }\end{array}$ & 40,00 & 50,00 & 66,67 \\
\hline 11 & $\begin{array}{l}\text { Menanggapi } \\
\text { pendapat orang } \\
\text { lain }\end{array}$ & 45,00 & 56,19 & 66,67 \\
\hline 12 & $\begin{array}{l}\text { Kemampuan } \\
\text { memasang } \\
\text { keramik } \\
\text { horizontal } \\
\end{array}$ & 56,67 & 66,67 & 73,33 \\
\hline 3 & $\begin{array}{l}\text { Kemampuan } \\
\text { memasang } \\
\text { keramik vertikal }\end{array}$ & 46,67 & 50,00 & 56,67 \\
\hline 14 & $\begin{array}{l}\text { Membuat } \\
\text { ringkasan atau } \\
\text { rangkuman } \\
\text { belajar }\end{array}$ & 50,00 & 56,67 & 66,67 \\
\hline & Rata-rata & 33,33 & 46,67 & 53,33 \\
\hline
\end{tabular}

Tabel 2. Aspek Yang Diukur Dari Peserta WBL (2)

\begin{tabular}{|c|c|c|c|}
\hline \multirow{2}{*}{ No } & \multirow{2}{*}{$\begin{array}{c}\text { Aspek yang } \\
\text { diukur dari } \\
\text { peserta }\end{array}$} & \multicolumn{2}{|c|}{$\begin{array}{l}\text { Minggu/perte } \\
\text { muan (\%) }\end{array}$} \\
\hline & & IV & V \\
\hline 1 & $\begin{array}{l}\text { Kemampuan } \\
\text { mengenal Alat } \\
\text { Pelindung Diri }\end{array}$ & 80,00 & 90,00 \\
\hline 2 & $\begin{array}{l}\text { Kemampuan } \\
\text { mengenal alat }\end{array}$ & 63,33 & 83,33 \\
\hline 3 & $\begin{array}{l}\text { Kemampuan } \\
\text { mengenal Bahan }\end{array}$ & 73,33 & 83,33 \\
\hline 4 & $\begin{array}{l}\text { Kemampuan } \\
\text { menggunakan } \\
\text { alat }\end{array}$ & 60,00 & 73,33 \\
\hline 5 & $\begin{array}{l}\text { Kemampuan } \\
\text { mengkomposisis } \\
\text { kan bahan }\end{array}$ & 83,33 & 93,33 \\
\hline 6 & $\begin{array}{l}\text { Memperhatikan } \\
\text { penjelasan dosen }\end{array}$ & 90,00 & 100,00 \\
\hline 7 & $\begin{array}{l}\text { Keberanian } \\
\text { bertanya }\end{array}$ & 70,00 & 76,67 \\
\hline 8 & $\begin{array}{l}\text { Kemampuan } \\
\text { bekerja mandiri }\end{array}$ & 80,00 & 83,33 \\
\hline 9 & $\begin{array}{l}\text { Berkomunikasi } \\
\text { dan } \\
\text { berpartisipasi } \\
\text { dengan baik }\end{array}$ & 70,00 & 76,67 \\
\hline 10 & $\begin{array}{l}\text { Kemampuan } \\
\text { kerja tim } \\
\end{array}$ & 76,67 & 90,00 \\
\hline 11 & $\begin{array}{l}\text { Menanggapi } \\
\text { pendapat orang } \\
\text { lain }\end{array}$ & 79,76 & 88,10 \\
\hline 12 & $\begin{array}{l}\text { Kemampuan } \\
\text { memasang } \\
\text { keramik } \\
\text { horizontal } \\
\end{array}$ & 80,00 & 90,00 \\
\hline 3 & $\begin{array}{l}\text { Kemampuan } \\
\text { memasang } \\
\text { keramik vertikal }\end{array}$ & 63,33 & 83,33 \\
\hline 14 & $\begin{array}{l}\text { Membuat } \\
\text { ringkasan atau } \\
\text { rangkuman } \\
\text { belajar }\end{array}$ & 73,33 & 83,33 \\
\hline & Rata-rata & 60,00 & 73,33 \\
\hline
\end{tabular}

Gambar 1 adalah diagram batang dari aspek penilaian yang dilakukan. Sumbu $x$ adalah empatbelas aspek yang dinili dan sumbu $\mathrm{Y}$ adalah persentase rata-rata daru setiap aspek. Dari Tabel 1 dapat dilihat adanya peningkatan persentase terhadap masing-masing aspek yang dinilai. Persentase yang meningkat tajam dapat dilihat pada 'kemampuan mengenal alat pelindung diri dan kemampuan mengenal bahan'. Peserta yang merupakan mahasiswa 


\section{Penerapan Work-Based Learning Terhadap Praktik Pemasangan Keramik Mahasiswa Pendidikan Teknik Bangunan}

pendidikan teknik bangunan adalah mahasiswa yang sebagian masih belum pernah mengenal dunia konstruksi. Sebelum memulai pekerjaan maka mahasiswa wajib mengetahui Alat pelindung Diri (APD) dan penggunaan APD. APD wajib digunakan selama pekerja berada dalam lingkungan pekerjaan ataupun selama melakukan pekerjaan. APD digunakan untuk mengurangi resiko yang terjadi akan kecelakaan kerja, sehingga kecelakaan yang terjadi selama berlangsungnya pekerjaan dapat diminimalisir. Diawal sebelum memulai pekerjaan peserta dikenalkan dengan APD, yang intinya peserta tidak begitu paham alat APD dan kegunaan APD ini terlihat dari persentase awal sebesar 50\%, tetapi seiring dengan pelaksanaan WBL dari minggu I sampai minggu keempat terjadi peningkatan dan diakhir minggu keempat mahasswa sudah $100 \%$ memahami kegunaan dan pemakaian APD. Begitu juga dengan pengenalan bahan yang dilakukan sebelum dan sesudah WBL, selama ini mahasiswa hanya sedikit yang mengenal bahan untuk konstruksi bangunan. Dengan WBL peserta dapat dengan aktif mengenal bahan, membedakan bahan dan penggunaaan. Dari ketigabelas aspek yang diukur tingkat keaktifannya, dengan WBL secara umum meningkat dibandingkan dengan sebelum menggunakan

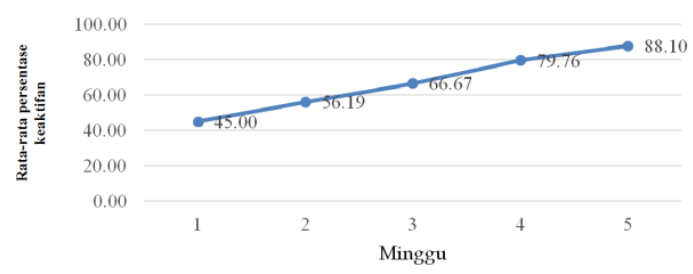

Gambar 1. Rata-rata persentase penilaian aspek peserta WBL

Dalam pembelajaran WBL yang dilakukan telah menunjukkan keberhasilan dalam pelaksanaannya, karena salah satu keuntungan WBL adalah peningkatan keaktifan peserta dalam proses pembelajaran. Peserta WBL sebanyak 30 orang, kemudian diamati tingkat kaeaktifannya selama penerapan WBL. Hasil sebaran keaktifan jumlah peserta yang diteliti dapat dilihat pada Tabel 3 dan Gambar 2 sebagai berikut
Tabel 3. Hasil Tingkat Keaktifan Peserta WBL

\begin{tabular}{|c|c|c|c|c|c|c|}
\hline \multirow{3}{*}{ No } & \multirow{3}{*}{$\begin{array}{l}\text { Indi } \\
\text { kator }\end{array}$} & \multicolumn{5}{|c|}{ Persentase (\%) } \\
\hline & & \multicolumn{5}{|c|}{ Minggu/Pertemuan } \\
\hline & & I & II & III & IV & $\mathbf{V}$ \\
\hline \multirow[t]{2}{*}{1} & Tidak & & & & & \\
\hline & Aktif & 56,67 & 40,00 & 26,67 & 16,67 & 16,67 \\
\hline 2 & Aktif & 33,33 & 40.00 & 26.67 & 40.00 & 33,33 \\
\hline \multirow[t]{2}{*}{3} & Cukup & & & & & \\
\hline & Aktif & 10,00 & 13,33 & 30,00 & 23,33 & 26,67 \\
\hline \multirow[t]{2}{*}{4} & Sangat & & & & & \\
\hline & Aktif & 0,00 & 6,67 & 16,67 & 20,00 & 23,33 \\
\hline \multicolumn{2}{|c|}{ Jumlah } & 100,00 & 100,00 & 100,00 & 100,00 & 100,00 \\
\hline
\end{tabular}

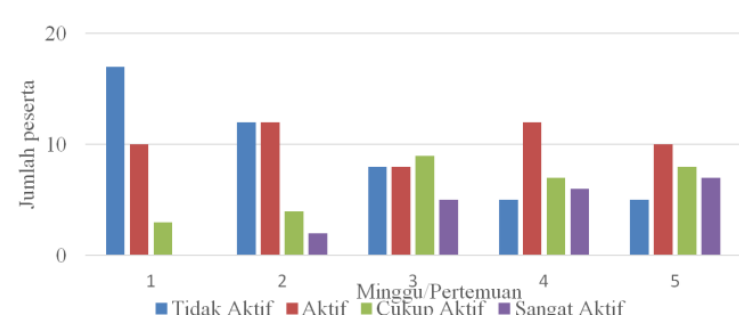

Gambar 2 Tingkat keaktifan peserta WBL

Mahasiswa Pendidikan Teknik Bangunan yang diberikan pembe-lajaran berbasis kerja di workshop Teknik Sipil merupakan sesuatu yang baru bagi mahasiswa sendiri. Umumnya peserta belum per-nah mendapatkan pengalaman belajar yang sesuai dengan tempat kerja. Gambar 2 menunjukkan tingkat keaktifan peserta WBL yang diamati selama proses pembelajaran. Perte-muan pertama adalah pertemuan dimana mahasiswa belum mendapat-kan ilmu ataupun belum mempunyai kemampuan dalam praktik batu beton. Oleh karena itu pada awal pertemuan peserta masih malu-malu, takut, dengan tingkat keaktifan dan partisipasi yang rendah dalam proses pembelajaran. Awalnya, jumlah peserta yang pasif sebesar 53,33\% (17 orang) seiring dan tidak seorangpun peserta yang sangat aktif. Melalui pembelajaran dengan WBL yang diberikan, maka jumlah siswa pasif berkurang menjadi 16,67 \% (5 orang). Hasil pengamatan terhadap peserta WBL yang tidak aktif sebanyak lima orang ini karena pengaruh perbedaan gender. Seperti diketahui bahwa peserta WBL adalah mahasiswa yang terdiri dari 17 laki-laki dan 13 perempuan. Umumnya para lelaki aktif dalam mengikuti WBL ini, tetapi mahasiswa perempuan cenderung kurang aktif selama proses pembelajaran. Selan-jutnya dengan pembela-jaran WBL yang dilakukan terlihat peningkatan yang signifikan dari setiap pertemuan. Peningkatan keaktifan mahasiswa ini diharapkan akan berimplikasi 


\section{Nono Sebayang - Syafiatun Siregar - Enny K. Sinaga}

pada hasil perolehan nilai akhir atau evaluasi terhadap kompe tensi masing-masing peserta

Tabel 4. Hasil Kompetensi Peserta WBL

\begin{tabular}{|c|c|c|c|c|c|c|}
\hline \multirow{3}{*}{ No } & \multirow{3}{*}{$\begin{array}{l}\text { Indi } \\
\text { kator }\end{array}$} & \multicolumn{5}{|c|}{ Persentase (\%) } \\
\hline & & \multicolumn{5}{|c|}{ Minggu/Pertemuan } \\
\hline & & I & II & III & IV & $\mathbf{V}$ \\
\hline \multirow[t]{2}{*}{1} & Tidak & & & & & \\
\hline & Kompeten & 83,33 & 60,00 & 36,67 & 26,67 & 16,67 \\
\hline 2 & Kompeten & 13,33 & 16,67 & 20,00 & 20,00 & 10,00 \\
\hline \multirow[t]{2}{*}{3} & Cukup & & & & & \\
\hline & Kompeten & 3,33 & 16,67 & 26,67 & 23,33 & 13,33 \\
\hline \multirow[t]{2}{*}{4} & Sangat & & & & & \\
\hline & Kompeten & 0,00 & 6,67 & 16,67 & 30,00 & 60,00 \\
\hline \multicolumn{2}{|r|}{ Jumlah } & 100,00 & 100,00 & 100,00 & 100,00 & 100,00 \\
\hline
\end{tabular}

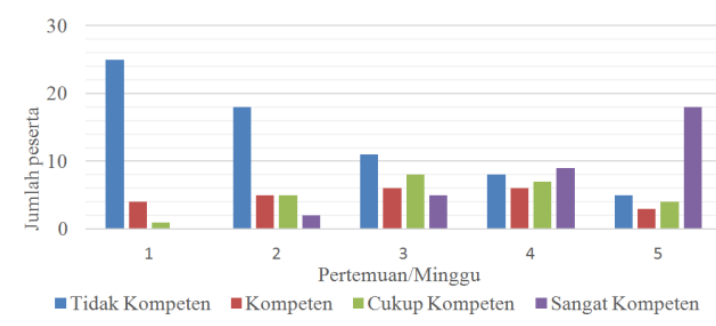

Gambar 3. Rekapitulasi hasil belajar peserta WBL

Tabel 4 dan Gambar 3 menunjukkan hasil belajar terhadap proses WBL yang dilakukan. Sumbu Y adalah jumlah peserta WBL, sedangkan sumbu $x$ adalah hasil evaluasi terhadap peserta WBL. Awalnya, dilakukan pretest (minggu/pertemuan 1) kepada peserta yang menghasilkan 83,33 \% yang tidak kompeten, tetapi seiring dengan pemberian WBL terjadi peningkatan menjadi $16,67 \%$ yang tidak kompeten. Seperti yang dijelaskan di gambar sebelumnya terdapat peserta yang kurang aktif dalam proses pembelajaran yang umumnya adalah peserta perempuan. Hal ini pun berdampak terhadap penilaian kompetensi yang dilakuka. Dari hasil pengamatan dan test yang dilakukan terdapat $16,67 \%$ peserta yang tidak kompeten, sehingga perlu lagi dilakukan terapi agar peserta tersebut dapat kompeten. Dari gambar tersebut terlihat peningkatan yang signifikan dari sebelum melakukan pembelajaran WBL, pembelajaran di minggu I sampai ke minggu ke 5

\section{Simpulan}

Dari hasil penelitian pada minggu pertama, menunjukkan bahwa terdapat perubahan pemahaman kognitif (kompetensi) peserta dalam melakukan pekerjaan finishing. dengan WBL. Dari Gambar 1, selisih skor ratarata tingkat keaktifan dari pada minggu pertama yaitu sebesar $45,00 \%, 56,19 \%, 66,67 \%$,
$79,76 \%$ dan88,10\% pada minggu/pertemuan kelima. Selisih rata-rata ini belum menujukkan perubahan yang besar bila dikaitkan dengan nilai kompetensi yang diharapkan. Untuk meningkatkan perubahan tersebut melalui WBL perlu dilakukan pembelajaran yang benar-benar sesuai dengan tempat kerja. Pelaksanaan WBL dapat dilanjutkan dengan melakukan pelatihan di tempat kerja (PKLI). Pelatihan di tempat kerja akan membantu pekerja konstruksi bangunan tentang dunia kerja yang sesungguhnya. Dengan melaksanakan WBL yang terbimbing, dimana setiap peserta aktif dalam berkomunikasi dan berpartispasi dalam melaksanakan pekerjaan finishing, maka pemahaman akan jauh lebih meningkat dibandingkan dengan tanpa WBL. Selanjutnya WBL dapat juga dilakukan bukan hanya untuk mahasiswa PTB tetapi terhadap seluruh mahasiswa pada jurusan Pendidikan Teknik Bangunan, tetapi bagi mahasiswa vokasi. Pemberian WBL dalam ruang kelas akan lebih meningkatkan kompetensi mahasiswa yang akan memasuki dunia kerjanya.

\section{Daftar Pustaka}

Ball, I., and Manwaring G., 2010, Making It Work, A Guidebook Exploring Work Based Learning,QAA, Scotland

Depdiknas. 2013, Reposisi pendidikan vokasi menjelang 2020. Jakarta : Direktorat Pendidikan Menengah Kejuruan.

Fink, K. F., Rokkjaer, O., \& Schrey, K. 2007, Work Based Learning And Facilitated Work Based Learning. Aalborg: TREE (Teaching and Research in Engineering in Europe).

Kamil, M., 2003, Model-model Pelatihan, Makalah, Universitas Pembangunan Indonesia

Komalasari K., $2013 . \quad$ Pembelajaran Kontekstual. Bandung: PT. Refika Aditama.

Linehan, M. 2008, Work-Based Learning, Graduating Through The Workplace, CIT Press, Bishopstown, Cork, Ireland

Lynch, R.L. \& Harnish, D. 1998. Preparing preservice teachers education students to used workbased strategies to improve instruction. In contextual teaching and learning : preparing teachers to enchance student success in the workplace and beyond (pp. 127-158). 
Columbus : OH : ERIC Dearinghouse on Adult, Career, and Vocational Education.

Morley, R. 2010. Workplace Learning Guide 2010: Learning for Life in the 21st Century. ED Options.

Sanjaya, W., 2005, Pembelajaran dalam Implementasi Kurikulum Berbasis Kompetensi, Edisi Pertama Cetakan Kedua, Kencana Prenada Group, Jakarta 